\title{
EFFECT OF SERVANT LEADERSHIP ON ORGANIZATION PRODUCTIVITY: A CASE STUDY DEPICTING THE LEBANESE BANKING SECTOR
}

\author{
Dr. Ahmad EL Zein, Lebanese International University \\ Rima Sharaf Aldine, Modern University for Business and Science \\ Manal Ahmad, Modern University for Business and Science \\ Dr. Chukri Akhras, Lebanese International University
}

\begin{abstract}
In business today, the term "Leadership" is gaining considerable attention in the various work fields ranging from education, politics, governmental organizations, religious sanctuary, and medical centers ... In their nature, humans are likely to have leader-follower relations; mainly, an insightful person with a better vision is likely to lead the group while the other group members who lack the clear vision and plan are likely to be followers. They follow since they trust and believe that their leader is capable of helping them survive in the various domains. Therefore, a definition of the term Leadership differs in relation to context, origin, styles and implications, yet what is universally agreed on is the common need for servant leaders; those with the sharp vision who can strive for greatness in economy, communities, and lives. In this article, the aim was to analyze the effect of servant leadership on organizational productivity among bank employees in Lebanon. The results showed the servant leadership is highly recognized by employees especially in the complex organizational structure of banks.
\end{abstract}

Keywords: Servant Leadership, organizational productivity, job satisfaction, Banks, Lebanon

\subsection{INTRODUCTION}

Many research attempted to define leadership types and functions; strategic planners worldwide believed that leadership carries a deeper meaning beyond gaining a top management position; it's even become a topic of debate for those who support the traditional way of leading and those calling for the change such as Greenleaf (1977) who described the need for a new type of leadership model - a model that puts serving others a priority; servant leadership emphasizes on serving others, enhancing a sense of community, and sharing the power of decision-making. Although servant leadership in a newly used word, it has been found since the time of Jesus and He used to implement it with His disciples and teach it for them. Sendjaya and Sarros (2002) said that, "Jesus Christ is model of Servant Leadership" (p.58). This fact shows the holiness and spirituality of such a style of leadership and emphasizes its significance in spreading love, peace, and happiness. According to Fry and Slocum (2008), creating a culture of selfless love enhances followers' feelings and makes them as better understood and appreciated. Such corporate culture makes employees passionate and belonging to the general code of ethics. Eva, Robin, Sendjaya, Dierendonck and Lidene (2019) said that, "servant leadership is a holistic leadership approach that engages followers in multiple dimensions (e.g., relational, ethical, emotional, spiritual), such that they are empowered to grow into what they are capable of becoming." (p. 111) 
Many countries are being aware of the impact of servant leadership on their economic, social, environmental, and cultural progress and growth. Eva et al. stated in their research that "Servant Leadership:

[Is] a systematic review and call for future research" that their study has been conducted across 39 countries from north America, Europe, South Asia, and others as Australia, Cyprus, India, Iran, Israel, South Africa, and Turkey, who are all concerned about studying the aspects and prominence of servant leadership notion.

In the case of Lebanon, which is a country with too many political, economic, and environmental problems caused by the leadership styles used. Yahchouchi (2009) explained a main leadership problem in the Lebanese context, stating the term exactly as the Lebanese use it: "WASTA is a common Arabic term used to indicate the act of supporting, favoring, and even being generous to a specific person within families or community networks in a way that may seem unfair to others. Sometimes WASTA is done disregarding competency" (p.127). Yahchouchi found that the division of the Lebanese society into different sects, resulted in having different leadership style perceptions between Muslim and Christian backgrounds. Moreover, Lebanon lacks servant leadership style due to the fact that the Lebanese don't mind following a high power distance approach where appreciating the notion of servant leaders is not found among most Lebanese leaders and followers as well; moreover, Lebanon lacks research on such a topic that may be the beginning of a solution for many of its problems, for that this study is conducted on the banking sector in Lebanon.

Based of the above, the purpose of this study is to examine the effect of servant leadership, if applied on the productivity of employees in banks in Lebanon. This study may be later expanded over other economic sectors as well as social, cultural, and governmental ones to improve people's lives and outcomes and spread awareness on the value of moving towards applying the basics and standards of the servant leadership style. In this regard, it's vital to refer Usman and Danish (2010) who stated that, "the philosophy of spirituality at the work places encourages the emotions of altruistic love, care, humanity, meaning creation, inner satisfaction, and selffulfillment” (p. 65).

\subsection{LITERATURE REVIEW}

\subsection{Servant Leadership}

Larry Spears (2010), president and CEO of The Larry C. Spears Center for Servant Leadership, who served as the president and CEO of The Robert K. Greenleaf Center for Servant Leadership from 1990 to 2007, explained that for many, servant and leader are two contradictory terms, but Greenleaf gave meaning to this paradoxical term "servant leadership". Since then, most thinkers are introducing servant leadership style as the leadership paradigm for $21^{\text {st }}$ century (Spears, 2010). Greenleaf (1977) defined servant leadership as:

The servant-leader is servant first. It begins with the natural feeling that one wants to serve. Then conscious choice brings one to aspire to lead. The best test is: do those served grow as persons: do they, while being served, become healthier, wiser, freer, more autonomous, more likely themselves to become servants? And, what is the effect on the least privileged in society; will they benefit, or, at least, not be further deprived? (p.27)

Again, Greenleaf (1977) explained servant leadership as, "It begins with the natural feeling that one wants to serve, to serve first. Then, conscious choice brings one to aspire to lead" (p. 10). 
Greenleaf (1977) added that crave to lead first and not to serve, is a result for the ambition to have control, power, and individual profits. In addition to that, Greenleaf (1977) discussed that the decision to lead or serve first, depends on the leader's personal characteristics and not leadership techniques.

Patterson, Russell, and Stone (2003) formed the Patterson's theory about servant leadership which included the below constructs that should be in a typical servant leader, briefly stating them as: They follow, lead, serve with love, act with humility, are altruistic, are visionary for the followers, are trustworthy and empowering for their followers.



Figure 1: Patterson's servant leadership model shows the flow and interaction of the constructs.

Source: Patterson (2003)

Indeed, Spears (2010) defined ten characteristics of servant leader:

1. Listening: Traditionally leaders are known for their listening skills, but servant leaders should listen to the words of others and to their inner voices that are not formed to words too.

2. Empathy: The success of a servant leader is in his ability to listen, accept, and understand others even if they are different and their performance or behavior seems to be unacceptable.

3. Healing: strength of servant leaders is to have the will and ability to heal suffering and broken spirits with themselves and with others.

4. Awareness: self-awareness is a special strength for a servant leader. Servant leaders should be more awake than disturbed, through seeing things from a holistic view and having their own inner serenity.

5. Persuasion: servant leaders are good at having consensus in groups through seeking to convince others rather than forcing them on something.

6. Conceptualization: servant leaders think beyond daily operations; they must stretch their thinking to more conceptual thinking for plans, missions, and vision.

7. Foresight: "Foresight is a characteristic that enables the servant leader to understand the lessons from the past, the realities of the present, and the likely consequence of a decision for the future" (p. 28).

8. Stewardship: servant leaders are committed to serve the needs of others and work for the greater benefit of societies.

9. Commitment to the Growth of People: a servant leader is tied by the personal and professional growth of every employee and colleague in his/her organization.

10. Building Community: a servant leader seeks to find some ways for building community among those who work with them as "servant leadership suggests that true community can be created among those who work in businesses and other institutions" (p.29). 
According to Sendjaya and Sarros (2002), Jesus Christ's model of leadership was the first where he told His disciples that, "You know that those who are regarded as rulers of the Gentlises lord it over them, and their high officials exercise authority over them. Not so with you. Instead, whoever wants to be great among you must be your servant" (NIV Bible, Mark 10:43).

Moreover, as it is known that Jesus applied servant leadership where, for example, one of His most revealing actions was washing the feet of His disciples.

According to Barnabas and Clifford (2012), in their article "Mahatma Gandhi- An Indian Model of Servant Leadership" where they explored the leadership qualities of Mahatma Gandhi according to six dimensions of the Servant Leadership Behavioral Scale (SLBS) model which is developed by Sendjaya, Sarros, and Santora in 2008. The six dimensions were: Voluntary Subordination (being a servant; acts of service), Authentic Self (humility; integrity; accountability; security; vunlerability), Covenantal Relationship (collaboration; equality; availability; acceptance), Responsible Morality (moral actions; moral reasoning), Transcendental Spirituality (religiousness; interconnectedness; sense of mission; wholeness), and Transforming Influence (trust; mentoring; modelling; vision; empowerement). Therefore, this study proved that Gandhi's characteristics that were analyzed in relation to the six dimensions of SLBS show clearly that Gandhi was a servant leader and can be a role model to new servant leaders.

\subsection{Job Satisfaction:}

After the research on various styles of leadership and job satisfaction, Laub (1999) concluded six job satisfaction variables that are: valuing people, developing people, developing community, displaying authenticity, providing leadership, and shares leadership; he included them in the Organizational Leadership Assessment (OLA). As stated earlier, all of these variables are key characteristics to servant leaders, which helps us achieve the effect of servant leadership on job satisfaction as positive. According to Greenleaf (1998), leader-follower relation in servant leadership is all about valuing each employee as an individual through recognition, acknowledgment, and understanding each person's strengths and weaknesses.

Stone et al. (2003) explained that unlike transformational leadership, servant leadership focuses on relations with employees as a priority and organizational profit as a less important aspect. Because of such values in servant leadership, employees' job satisfaction should increase, as when employees feel their value, they'll be more satisfied. Stone and Patterson (2005) explained that servant leadership works on developing followers through allowing them to work freely by allowing their creativity to flow and also by assigning them additional responsibilities and duties at work. This would reflect to employees that the primary emphasis is on the needs and desires of the followers and not the needs of the leader, which would boost personal development and empowerment of followers. This leader-follower relation will definitely increase job satisfaction among employees.

A study done by Cerit (2009) to prove the effect of servant leadership style of school principals on teachers' job satisfaction, the study showed that school principals should be servant leaders in order to improve teachers' job satisfaction since servant leadership has a positive impact on job satisfaction. Another study conducted by Anderson (2005), also focused on the correlation between servant leadership and job satisfaction which was significant. Anderson (2005) recommended that these obtained results should increase the training for servant leadership practices to improve leader-follower relations. 
Moreover, the job characteristics model by Hackman and Oldham (1976) confirmed the relation between basic human needs and job satisfaction. Emphasizing on this, Mayer, Bardes, and Piccolo (2008) in their study titled "Do servant-leaders help satisfy follower needs? An organizational justice perspective" found that servant leaders have essential role in satisfying their followers' needs and lately increasing job satisfaction among them. The findings of this study show an impact of servant leadership on job satisfaction through the mediator justice perceptions and need satisfaction.

\subsection{Productivity}

According to Savage-Austin and Honeycutt (2011), the benefits of fostering servant leadership in organizations include better decisions, increased productivity, higher morale, and fewer turnovers. Laub (1999) proposed that "managers and workers would have higher job satisfaction in a servant organization and as a result would be freed up to perform at their highest levels of ability, leading to greater success for the organization" (p. 85).

McNeese-Smith (1997) said that organizational research showed that employees who are satisfied with their jobs are probably more productive and committed to the job. The metaanalytical study by Irvine and Evans (1995) emphasized this idea too. On the other hand, Gangadhraiah, Nardev, and Reddy (1990) explained the negativity of job dissatisfaction that leads to absenteeism, problems from increased complaints, low morale, and higher turnovers.

Freeman (2010) argued that spirituality is one of the main characteristics and factors that raise servant leaders. Sendjaya, Sarros, and Santora (2008) added that looking at the similarities between spirituality and servant leadership, one could speculate that servant leadership is part of the concept of spirituality. The research conducted by Burton and O'Reilly (2000) provided that enhancing the spiritual and religious values within the organization especially among managerial levels offers a significant impact on the organizational productivity. Wilkes (1998) claimed that spiritual leaders are responsible about reforming employees' personality and building their characters by empowering them, relying on them, and trusting them to have greater levels of job satisfaction that help in accomplishing the company's vision.

Usman and Danish (2010) in their study that investigated the impact of work spirituality on the job satisfaction of branch managers, area managers and regional managers of the banking sector of Pakistan, concluded that,

The results are found quite significant ensuring the fact that job satisfaction is greatly influenced by work spirituality. The spiritual dogmas like power of transcendence and values of transformational leader ship i.e. affection, meaning creation, altruistic love, wholeness and inter connectedness leads to individual's strong sense of fulfillment from the job in the form of organizational accomplishment. The orientation of spirituality in the organizational culture leads to greater satisfaction and productivity of employees with a sense of calling membership. (p.68)

Leadership spirituality motivates the organization employees and improves their mental awareness and perception by building a sense of unity and success that makes them more dedicated and loyal towards their organizational growth and progress (Bass, 1998). Markow and Klenke (2005) and Milliman, Czaplewski and Ferguson (2003) argued that spiritual leadership has a great positive impact on employees' productivity, organizational attachment, affiliation, commitment and decreasing turn overs. Leadership spirituality is accompanied with emotional attachment to the organizations, as according to Fry, Vitucci, and Cedillo (2003) spiritual and 
God's values emphasize on love, care, and innovation, which create an internal link with their work place and enhances the levels of employees' job satisfaction and accomplishment resulting in better organizational productivity.

According to Aydin and Ceylan (2009), leadership spirituality, which includes the values of love, care, affiliation, perfection, and loyalty, enhances employees' connections to their organization and provides employees with better capabilities and better productivity. In addition, in today's business world, organizations' performance, productivity, and competence are exclusively derived from leadership spirituality (Chopra, 2002). Avolio and Gibbons (1988) said that the goal of leadership spirituality is to create an organizational culture that empowers the employees morally and ethically making them intrepid, certain, and qualified. As a result, employees' job involvement and job satisfaction increase. They added spiritual leaders motivate the employees intrinsically to have internal focus on organizational growth and progress through matching their individual values with the organization's values and mission.

\subsection{METHODOLOGY}

\subsection{Introduction}

This study examined the effect that servant leaders can have on their employees. It attempts to measure the level of interaction between the employees and their servant leaders. The study is based on the participation in the servant leadership model of employees in private Lebanese banks that have part-time or full-time jobs as self-reported by the participants themselves in a survey that they answered. This chapter covers the following areas: research design, research questions, sample selection, data collection, and data analysis. The independent variable for the research question was the effect of the servant leader measured based on an approved model, and the dependent variable was the criteria of productivity of employees measured through a validated model.

\subsection{Research Design}

In this research, a mixed method was used. A combination between quantitative and qualitative methods. In quantitative research methodology, the researcher depends on numbers to analyze and interpret data from a large number of respondents. This is usually impossible to assess with qualitative methods (Nardi, 2003). On the other hand, qualitative research attempts to use a variety of methods to "gain insight into individuals' lives" (Denzin \& Lincoln, 2000). Based on the interpretation of Marshall and Rossman (1999), qualitative research is "pragmatic, interpretive, and grounded in the lived experiences of people". The used quantitative approach adopted by this study was based on administering a revised "Servant Leadership Profile" (SLP) to fifty participants, most of them are employees in the banking sector. The qualitative part was covered by interviewing a combination of managers, assuming the role of leaders at different positions in the Lebanese market.

\subsection{Research Questions}

Different attempts were taken to formulate the research question. The intention was to come-up with a research question that is: researchable, simple, interesting, properly defined, and interesting (Hulley, Stephen B, etal, 2007). The resulting research questions were identified:

1- To what extent do Lebanese young employees identify their managers as servant leaders? 
2- To what extent is servant leadership practiced by managers has positive impact on the productivity of young employees in the Lebanese banking sector?

\subsection{Sample Selection}

For Polit and Hungler (1999), population is the aggregation of all different "objects, subjects or members that conform to a set of specifications". In this study the population consisted of all employees of privately owned and for-profit business organizations in Lebanon. Based on the extent and the geographical area that the population covers, the non-probability sampling method was used for this study. Convenience sampling was employed, as readily accessible employees from the students enrolled at different universities were approached to participate in the study (Zikmund, Babin, Carr \& Griffin, 2009). Furthermore, snowball sampling was used to identify additional respondents for inclusion in the study. A total of 100 students were reached, only 72 of them responded and filled the questionnaire that was shared publicly with them using Google Forms. A 72\% response rate. For Fincham J. E. (2008), a survey response rate of 50\% or higher might be considered excellent in most cases.

\subsection{Data Collection}

Using online library databases of peer-reviewed journal articles, papers, and books, secondary data was collected through comprehensive literature reviews of the research variables. The primary data for this analysis was gathered using a combination of self-administered Google Form, Internet Online-based questionnaires using the survey process.

\subsection{Questionnaire Design}

A combination of self-constructed questions developed from the literature review as well as accurate and relevant items adapted from previous studies was the questionnaire used in this research. The first part of questionnaire requested biographical details on the age, gender, industry sector, type of organization, and education level of the respondents. The second part of the questionnaire consisted of elements assessing expectations of servant leadership based on a revised "Servant Leadership Profile" (SLP) model. The third part assessed the employees' engagement in the organization. The fourth part of the questionnaire checked the employees' retention, while the fifth and last part assessed the employees' satisfaction.

\subsection{Data Analysis}

The first phase in the analysis of the results involved the assessment of the validity and reliability of the questionnaire. Content relevance was assured by the application of a questionnaire to professionals in the area of leadership and organizational success. The prototypes of the hypothesized model in this study were subjected to factor analysis in order to assess the converging validity of the model. Principle component analysis (PCA) was used as a method of extraction of the factor. Unrotated variables have been used to determine the construct validity of the measurement instrument (Zikmund et al., 2009). The preservation of factors was identified by applying the Kaiser-Guttmann rule which states that factors having an explained variance (eigenvalue) greater than one is considered significant and may be retained for further interpretation (Kaiser, 1991; Zikmund et al., 2009; Hair et al., 2014). The obtained eigenvalues demonstrate the amount of shared variance accounted for by the respective number of items (Kaiser, 1991). The internal consistency method calculating Cronbach's coefficient alpha was used to assess the reliability of the measuring instrument for this study. A coefficient value of $0.979>0.70$ for each factor was deemed acceptable (Nunnally \& Bernstein, 1994). 
Furthermore, data collected from the Revised - Servant Leadership Profile (SLP) including the demographic questionnaire were analyzed using Page and Wong's Coding Key supplied with the Revised - Servant Leadership Profile survey. The coding key yielded a score for each of the factors for each individual respondent and a group mean and standard deviation.

\begin{tabular}{|l|l|}
\hline \multicolumn{2}{|c|}{ Reliability Statistics } \\
\hline $\begin{array}{l}\text { Cronbach's } \\
\text { Alpha }\end{array}$ & $\mathrm{N} \quad$ of \\
\hline .979 & 58 \\
\hline
\end{tabular}

\section{Demographic Results}

\begin{tabular}{|l|l|l|l|l|l|}
\hline \multicolumn{2}{|l|}{ Gender } & $\begin{array}{l}\text { Frequen } \\
\text { cy }\end{array}$ & $\begin{array}{l}\text { Percen } \\
\mathrm{t}\end{array}$ & $\begin{array}{l}\text { Valid } \\
\text { Percent }\end{array}$ & $\begin{array}{l}\text { Cumulative } \\
\text { Percent }\end{array}$ \\
\hline \multirow{2}{*}{$\begin{array}{l}\text { Val } \\
\text { id }\end{array}$} & $\begin{array}{l}\text { Fema } \\
\text { le }\end{array}$ & 52 & 72.2 & 72.2 & 72.2 \\
\cline { 2 - 6 } & Male & 20 & 27.8 & 27.8 & 100.0 \\
\cline { 2 - 6 } & Total & 72 & 100.0 & 100.0 & \\
\hline
\end{tabular}

Table 1: Gender

A total of 72 respondents answered the survey, $72 \%$ were females while $28 \%$ were Male.

\begin{tabular}{|l|l|l|l|l|l|}
\hline \multicolumn{2}{|l|}{ Age } & $\begin{array}{l}\text { Frequen } \\
\text { cy }\end{array}$ & $\begin{array}{l}\text { Percen } \\
\mathrm{t}\end{array}$ & $\begin{array}{l}\text { Valid } \\
\text { Percent }\end{array}$ & $\begin{array}{l}\text { Cumulative } \\
\text { Percent }\end{array}$ \\
\hline \multirow{3}{*}{$\begin{array}{l}\text { Val } \\
\text { id }\end{array}$} & $18-27$ & 34 & 47.2 & 47.2 & 47.2 \\
\cline { 2 - 6 } & $28-37$ & 14 & 19.4 & 19.4 & 66.7 \\
\cline { 2 - 6 } & $38-47$ & 20 & 27.8 & 27.8 & 94.4 \\
\cline { 2 - 6 } & $\begin{array}{l}48 \text { and } \\
\text { above }\end{array}$ & 4 & 5.6 & 5.6 & 100.0 \\
\cline { 2 - 6 } & \begin{tabular}{l} 
Total \\
\hline
\end{tabular} & 72 & 100.0 & 100.0 & \\
\hline
\end{tabular}

Table 2: Age 
9 | International Journal of Scientific and Management Research 04 (04) 01-20

The age range of the participants was between 18 and 48 or above. The majority of the participants (34) were between 18 and 27, while only 4 were 48 and above (Table 2)

\begin{tabular}{|c|c|c|c|c|c|}
\hline \multicolumn{6}{|c|}{ Which of the following best describes your role in industry? } \\
\hline & & $\begin{array}{l}\text { Frequen } \\
\text { cy }\end{array}$ & $\begin{array}{l}\text { Percen } \\
\mathrm{t}\end{array}$ & $\begin{array}{l}\text { Valid } \\
\text { Percent }\end{array}$ & $\begin{array}{l}\text { Cumulative } \\
\text { Percent }\end{array}$ \\
\hline \multirow[t]{12}{*}{$\begin{array}{l}\text { Val } \\
\text { id }\end{array}$} & $\begin{array}{l}\text { Administrative } \\
\text { Staff }\end{array}$ & 8 & 11.1 & 11.1 & 11.1 \\
\hline & Consultant & 10 & 13.9 & 13.9 & 25.0 \\
\hline & $\begin{array}{l}\text { Junior } \\
\text { Management }\end{array}$ & 8 & 11.1 & 11.1 & 36.1 \\
\hline & $\begin{array}{l}\text { Middle } \\
\text { Management }\end{array}$ & 8 & 11.1 & 11.1 & 47.2 \\
\hline & Other & 4 & 5.6 & 5.6 & 52.8 \\
\hline & Researcher & 2 & 2.8 & 2.8 & 55.6 \\
\hline & Skilled Laborer & 12 & 16.7 & 16.7 & 72.2 \\
\hline & Student & 4 & 5.6 & 5.6 & 77.8 \\
\hline & $\begin{array}{l}\text { Temporary } \\
\text { Employee }\end{array}$ & 4 & 5.6 & 5.6 & 83.3 \\
\hline & $\begin{array}{l}\text { Trained } \\
\text { Professional }\end{array}$ & 8 & 11.1 & 11.1 & 94.4 \\
\hline & $\begin{array}{l}\text { Upper } \\
\text { Management }\end{array}$ & 4 & 5.6 & 5.6 & 100.0 \\
\hline & Total & 72 & 100.0 & 100.0 & \\
\hline
\end{tabular}

\section{Table 3: Industry}

The participants worked in a variety of industries. The majority worked as skilled labor or consultants (Table 3).

The organization you work for is in which of the following

\begin{tabular}{|l|l|l|l|l|l|}
\hline \multicolumn{2}{|l|}{} & $\begin{array}{l}\text { Frequen } \\
\text { cy }\end{array}$ & $\begin{array}{l}\text { Percen } \\
\mathrm{t}\end{array}$ & $\begin{array}{l}\text { Valid } \\
\text { Percent }\end{array}$ & $\begin{array}{l}\text { Cumulative } \\
\text { Percent }\end{array}$ \\
\hline Val & 2 & 2.8 & 2.8 & 2.8 \\
\hline
\end{tabular}


10 | International Journal of Scientific and Management Research 04 (04) 01-20

\begin{tabular}{|l|l|l|l|l|l|}
\hline id & Don't know & 4 & 5.6 & 5.6 & 8.3 \\
\cline { 2 - 6 } & Not-for-profit sector & 6 & 8.3 & 8.3 & 16.7 \\
\hline $\begin{array}{l}\text { Other } \\
\begin{array}{l}\text { Private sector (e.g. } \\
\text { most businesses and } \\
\text { individuals) }\end{array}\end{array} \quad 38$ & 52.8 & 52.8 & 75.0 \\
\hline $\begin{array}{l}\text { Public sector (e.g. } \\
\text { government) }\end{array}$ & 18 & 25.0 & 25.0 & 100.0 \\
\hline \begin{tabular}{l} 
Total \\
\hline
\end{tabular} & 72 & 100.0 & 100.0 & 22.2 \\
\hline
\end{tabular}

Table 4: Type of Organization

The participants worked at different organizational types. The majority (38) worked in private companies (Table 4)

\begin{tabular}{|c|c|c|c|c|c|}
\hline \multicolumn{6}{|c|}{ Please indicate the highest level of education completed } \\
\hline & & $\begin{array}{l}\text { Frequen } \\
\text { cy }\end{array}$ & $\begin{array}{l}\text { Percen } \\
\mathrm{t}\end{array}$ & $\begin{array}{l}\text { Valid } \\
\text { Percent }\end{array}$ & $\begin{array}{l}\text { Cumulative } \\
\text { Percent }\end{array}$ \\
\hline \multirow[t]{8}{*}{$\begin{array}{l}\text { Val } \\
\text { id }\end{array}$} & $\begin{array}{l}\text { College Graduate ( } 4 \\
\text { year - BS/BA) }\end{array}$ & 30 & 41.7 & 41.7 & 41.7 \\
\hline & $\begin{array}{l}\text { Doctoral Degree } \\
(\mathrm{PhD})\end{array}$ & 2 & 2.8 & 2.8 & 44.4 \\
\hline & $\begin{array}{l}\text { High School or } \\
\text { equivalent }\end{array}$ & 6 & 8.3 & 8.3 & 52.8 \\
\hline & $\begin{array}{l}\begin{array}{l}\text { Master's } \\
(\mathrm{MS})\end{array} \\
\end{array}$ & 28 & 38.9 & 38.9 & 91.7 \\
\hline & Other & 2 & 2.8 & 2.8 & 94.4 \\
\hline & $\begin{array}{l}\text { Professional Degree } \\
(\mathrm{MD}, \mathrm{JD}, \text { etc. })\end{array}$ & 2 & 2.8 & 2.8 & 97.2 \\
\hline & $\begin{array}{l}\text { Vocational/Technical } \\
\text { School ( } 2 \text { year) }\end{array}$ & 2 & 2.8 & 2.8 & 100.0 \\
\hline & Total & 72 & 100.0 & 100.0 & \\
\hline
\end{tabular}

Table 5: Education Level 
The participants belonged to different educational levels, the majority distributed between BS/BA holders (30) or MS/MBA holders (28) (Table 5)

\subsection{Descriptive Analysis}

From Table 6: Descriptive Analysis it is evident that the lowest mean score was found for Putting Subordinates at 3.91 While Employee Engagement Dedication the highest at 5.60. First Servant leadership at 4.694 and the remaining variables varied between 4.52 and 5.53. The mean scores indicate that respondents agreed somewhat with all the items measuring the different variables of the study.

\begin{tabular}{|c|c|c|c|c|c|c|}
\hline \multicolumn{7}{|l|}{ Descriptive Statistics } \\
\hline & $\mathrm{N}$ & $\begin{array}{l}\text { Minim } \\
\text { um }\end{array}$ & $\begin{array}{l}\text { Maxim } \\
\text { um }\end{array}$ & Mean & $\begin{array}{l}\text { Std. } \\
\text { Deviation }\end{array}$ & $\begin{array}{l}\text { Varian } \\
\text { ce }\end{array}$ \\
\hline $\begin{array}{l}\text { Empowering } \\
\text { Leadership }\end{array}$ & 72 & 1.0 & 7.0 & 4.522 & 1.4491 & 2.100 \\
\hline $\begin{array}{l}\text { Helping Subordinates } \\
\text { Grow \&amp; } \\
\text { Succeed }\end{array}$ & 72 & 1.2 & 7.0 & 4.739 & 1.3972 & 1.952 \\
\hline $\begin{array}{l}\text { Putting Subordinates } \\
\text { First }\end{array}$ & 72 & 1.0 & 7.0 & 3.919 & 1.3996 & 1.959 \\
\hline Servant Leadership & 72 & 1.8 & 7.0 & 4.694 & 1.4605 & 2.133 \\
\hline $\begin{array}{l}\text { Employee } \\
\text { Engagement - Vigor }\end{array}$ & 72 & 2.8 & 7.0 & 5.194 & 1.2093 & 1.463 \\
\hline $\begin{array}{l}\text { Employee } \\
\text { Engagement } \\
\text { Dedication }\end{array}$ & 72 & 2.2 & 7.0 & 5.600 & 1.3258 & 1.758 \\
\hline $\begin{array}{l}\text { Employee } \\
\text { Engagement } \\
\text { Absorption }\end{array}$ & 72 & 2.8 & 7.0 & 5.533 & 1.2472 & 1.555 \\
\hline Employee Retention & 72 & 2.4 & 7.0 & 4.819 & 1.0524 & 1.108 \\
\hline $\begin{array}{l}\text { Employee } \\
\text { Satisfaction }\end{array}$ & 72 & 2.3 & 7.0 & 5.208 & 1.3356 & 1.784 \\
\hline Valid N (listwise) & 72 & & & & & \\
\hline
\end{tabular}

Table 6: Descriptive Analysis

3.9 Regression Analysis 
Table 7: Regression Analysis, explains the regression results obtained for the influence of Servant leadership on the dimensions of the organizational performance based on the categories obtained from the revised "Servant Leadership Profile" (SLP).

\begin{tabular}{|l|l|l|l|l|}
\hline \multicolumn{5}{|c|}{ Model Summary } \\
\begin{tabular}{|l|l|l|} 
Mo \\
del
\end{tabular} & $\mathrm{R}$ & $\begin{array}{l}\mathrm{R} \\
\text { Square }\end{array}$ & $\begin{array}{l}\text { Adjusted R } \\
\text { Square }\end{array}$ & $\begin{array}{l}\text { Std. Error } \\
\text { of the } \\
\text { Estimate }\end{array}$ \\
\hline 1 & $.652^{\mathrm{a}}$ & .425 & .417 & 1.1065 \\
\hline \multicolumn{5}{|l}{} \\
a. Predictors: (Constant), Servant Leadership
\end{tabular}

Table 7a

\begin{tabular}{|l|l|l|l|l|}
\hline \multicolumn{5}{|c|}{ Model Summary } \\
\begin{tabular}{|l|l|l|} 
Mo \\
del
\end{tabular} & $\mathrm{R}$ & $\begin{array}{l}\mathrm{R} \\
\text { Square }\end{array}$ & $\begin{array}{l}\text { Adjusted R } \\
\text { Square }\end{array}$ & $\begin{array}{l}\text { Std. Error } \\
\text { of the } \\
\text { Estimate }\end{array}$ \\
\hline 1 & $.711^{\mathrm{a}}$ & .505 & .498 & .9899 \\
\hline \multicolumn{5}{|l|}{} \\
\hline
\end{tabular}

Table 7b

\begin{tabular}{|l|l|l|l|l|}
\hline \multicolumn{5}{|l|}{ Model Summary } \\
\begin{tabular}{|l|l|l|} 
Mo \\
del
\end{tabular} & $\mathrm{R}$ & $\begin{array}{l}\mathrm{R} \\
\text { Square }\end{array}$ & $\begin{array}{l}\text { Adjusted R } \\
\text { Square }\end{array}$ & $\begin{array}{l}\text { Std. Error } \\
\text { of } \\
\text { Estimate }\end{array}$ \\
\hline 1 & $.849^{\mathrm{a}}$ & .721 & .717 & .7451 \\
\hline \multicolumn{5}{|l|}{} \\
a. Predictors: (Constant), Servant Leadership \\
\hline
\end{tabular}

Table 7c

\begin{tabular}{|l|l|l|l|l|}
\hline \multicolumn{5}{|l|}{ Model Summary } \\
\hline $\begin{array}{l}\text { Mo } \\
\text { del }\end{array}$ & $\mathrm{R}$ & $\begin{array}{l}\mathrm{R} \\
\text { Square }\end{array}$ & $\begin{array}{l}\text { Adjusted R } \\
\text { Square }\end{array}$ & $\begin{array}{l}\text { Std. Error } \\
\text { of the } \\
\text { Estimate }\end{array}$ \\
\hline 1 & $.514^{\mathrm{a}}$ & .265 & .254 & 1.0444 \\
\hline \multicolumn{5}{|l|}{} \\
a. Predictors: (Constant), Servant Leadership \\
\hline
\end{tabular}


Table 7d

\begin{tabular}{|l|l|l|l|l|}
\hline \multicolumn{5}{|l|}{ Model Summary } \\
\hline $\begin{array}{l}\text { Mo } \\
\text { del }\end{array}$ & $\mathrm{R}$ & $\begin{array}{l}\mathrm{R} \\
\text { Square }\end{array}$ & $\begin{array}{l}\text { Adjusted R } \\
\text { Square }\end{array}$ & $\begin{array}{l}\text { Std. Error } \\
\text { of the } \\
\text { Estimate }\end{array}$ \\
\hline 1 & $.584^{\mathrm{a}}$ & .341 & .331 & 1.0842 \\
\hline \multicolumn{5}{|l}{} \\
\hline
\end{tabular}

Table 7e

\begin{tabular}{|l|l|l|l|l|}
\hline \multicolumn{5}{|l|}{ Model Summary } \\
\begin{tabular}{|l|l} 
Mo \\
del
\end{tabular} & $\mathrm{R}$ & $\begin{array}{l}\mathrm{R} \\
\text { Square }\end{array}$ & $\begin{array}{l}\text { Adjusted R } \\
\text { Square }\end{array}$ & $\begin{array}{l}\text { Std. Error } \\
\text { of the } \\
\text { Estimate }\end{array}$ \\
\hline 1 & $.517^{\mathrm{a}}$ & .267 & .257 & 1.0752 \\
\hline \multicolumn{5}{|l}{} \\
\hline
\end{tabular}

Table 7f

\begin{tabular}{|l|l|l|l|l|}
\hline \multicolumn{5}{|l|}{ Model Summary } \\
\hline $\begin{array}{l}\text { Mo } \\
\text { del }\end{array}$ & $\mathrm{R}$ & $\begin{array}{l}\mathrm{R} \\
\text { Square }\end{array}$ & $\begin{array}{l}\text { Adjusted R } \\
\text { Square }\end{array}$ & $\begin{array}{l}\text { Std. Error } \\
\text { of the } \\
\text { Estimate }\end{array}$ \\
\hline 1 & $.574^{\mathrm{a}}$ & .330 & .320 & .8677 \\
\hline \multicolumn{5}{|l}{} \\
\hline
\end{tabular}

Table $7 \mathrm{~g}$

\begin{tabular}{|l|l|l|l|l|}
\hline \multicolumn{5}{|l|}{ Model Summary } \\
\hline $\begin{array}{l}\text { Mo } \\
\text { del }\end{array}$ & $\mathrm{R}$ & $\begin{array}{l}\mathrm{R} \\
\text { Square }\end{array}$ & $\begin{array}{l}\text { Adjusted R } \\
\text { Square }\end{array}$ & $\begin{array}{l}\text { Std. Error } \\
\text { of the } \\
\text { Estimate }\end{array}$ \\
\hline 1 & $.708^{\mathrm{a}}$ & .501 & .494 & .9498 \\
\hline \multicolumn{5}{|l|}{} \\
\hline
\end{tabular}

Table $7 \mathrm{~h}$ 
Table 7a shows the results of the regression analyses that Servant leadership explain $42.5 \%$ of the variance in Empowering Leadership performance $(\mathrm{R} 2=0.425)$. Table $7 \mathrm{~b}$ shows the results of the regression analyses that Servant leadership explain $50.5 \%$ of the variance in Helping Subordinates Grow performance and Succeed $(\mathrm{R} 2=0.505)$. Table $7 \mathrm{c}$ shows the results of the regression analyses that Servant leadership explain $72.1 \%$ of the variance in Putting Subordinates First performance $(\mathrm{R} 2=0.721)$. Table $7 \mathrm{~d}$ shows the results of the regression analyses that Servant leadership explain 26.5\% of the variance in Employee Engagement - Vigor performance $(\mathrm{R} 2=0.265)$. Table $7 \mathrm{e}$ shows the results of the regression analyses that Servant leadership explain $34.1 \%$ of the variance in Employee Engagement - Dedication performance $(\mathrm{R} 2=0.341)$. Table $7 \mathrm{f}$ shows the results of the regression analyses that Servant leadership explain $26.7 \%$ of the variance in Employee Engagement - Absorption performance $(\mathrm{R} 2=0.267)$. Table $7 \mathrm{~g}$ shows the results of the regression analyses that Servant leadership explain $33.0 \%$ of the variance in Employee Retention performance $(\mathrm{R} 2=0.330)$. Table 7 h shows the results of the regression analyses that Servant leadership explain $50.1 \%$ of the variance in Employee Satisfaction performance $(\mathrm{R} 2=0.501)$.

\begin{tabular}{|c|c|c|c|c|c|c|}
\hline \multicolumn{7}{|c|}{ ANOVA $^{a}$} \\
\hline \multicolumn{2}{|c|}{ Model } & Sum of & $\mathrm{df}$ & Mean & $\mathrm{F}$ & Sig. \\
\hline \multirow[t]{3}{*}{1} & $\begin{array}{l}\text { Regressi } \\
\text { on }\end{array}$ & 63.379 & 1 & 63.379 & 51.764 & $.000^{\mathrm{b}}$ \\
\hline & Residual & 85.706 & 70 & 1.224 & & \\
\hline & Total & 149.084 & 71 & & & \\
\hline \multicolumn{7}{|c|}{ a. Dependent Variable: Empowering Leadership } \\
\hline
\end{tabular}

\begin{tabular}{|c|c|c|c|c|c|c|}
\hline \multicolumn{7}{|c|}{ Coefficients $^{\mathrm{a}}$} \\
\hline \multicolumn{2}{|c|}{ Model } & \multicolumn{2}{|c|}{$\begin{array}{l}\text { Unstandardized } \\
\text { Coefficients }\end{array}$} & \multirow{2}{*}{$\begin{array}{l}\text { Standardize } \\
\mathrm{d} \\
\text { Coefficient } \\
\mathrm{s}\end{array}$} & \multirow[t]{2}{*}{$\mathrm{t}$} & \multirow[t]{2}{*}{ Sig. } \\
\hline & & B & Std. Error & & & \\
\hline \multirow[t]{2}{*}{1} & $($ Constant $)$ & 1.485 & .442 & & 3.362 & .001 \\
\hline & $\begin{array}{l}\text { Servant } \\
\text { Leadership }\end{array}$ & .647 & .090 & .652 & 7.195 & .000 \\
\hline
\end{tabular}




\section{Table 8a}

Furthermore, from Table 8a Servant leadership explains a significant proportion of the variance in the dependent variable Empowering Leadership performance $(F=51.764 ; p<0.05)$, and was found to have a significant and positive impact on Empowering Leadership performance $\left(\mathrm{b}^{*}=\right.$ 0.647; $\mathrm{p}<0.05)$. Empowering Leadership performance in this study was measured by soliciting perceptions regarding the employees' performance. This finding therefore indicates that Servant leadership is predicted to significantly improve employees' performance.

\begin{tabular}{|l|l|l|l|l|l|l|}
\hline \multicolumn{2}{|c|}{ ANOVA ${ }^{-2}$ Model } & $\begin{array}{l}\text { Sum of } \\
\text { Squares }\end{array}$ & df & $\begin{array}{l}\text { Mean } \\
\text { Square }\end{array}$ & F & Sig. \\
\hline \multirow{2}{*}{1} & $\begin{array}{l}\text { Regressi } \\
\text { on }\end{array}$ & 70.022 & 1 & 70.022 & 71.462 & $.000^{\mathrm{b}}$ \\
\cline { 2 - 7 } & Residual & 68.589 & 70 & .980 & & \\
\cline { 2 - 7 } & Total & 138.611 & 71 & & & \\
\hline \\
a. Dependent Variable: Helping Subordinates Grow \& Succeed \\
\hline \\
b. Predictors: (Constant), Servant Leadership \\
\hline
\end{tabular}

\begin{tabular}{|c|c|c|c|c|c|c|}
\hline \multicolumn{7}{|c|}{ Coefficients $^{\mathbf{a}}$} \\
\hline \multirow{2}{*}{\multicolumn{2}{|c|}{ Model }} & \multicolumn{2}{|c|}{$\begin{array}{l}\text { Unstandardized } \\
\text { Coefficients }\end{array}$} & \multirow{2}{*}{$\begin{array}{l}\text { Standardize } \\
\text { d } \\
\text { Coefficient } \\
\text { S } \\
\text { Beta }\end{array}$} & \multirow[t]{2}{*}{$\mathrm{t}$} & \multirow[t]{2}{*}{ Sig. } \\
\hline & & B & Std. Error & & & \\
\hline \multirow[t]{2}{*}{1} & (Constant) & 1.547 & .395 & & 3.914 & .000 \\
\hline & $\begin{array}{l}\text { Servant } \\
\text { Leadership }\end{array}$ & .680 & .080 & .711 & 8.454 & .000 \\
\hline
\end{tabular}

\section{Table 8b}

Furthermore, from Table 8b Servant leadership explains a significant proportion of the variance in the dependent variable Helping Subordinates Grow \& Succeed performance $(\mathrm{F}=71.462 ; \mathrm{p}<$ 0.05), and was found to have a significant and positive impact on Helping Subordinates Grow and Succeed performance $\left(b^{*}=0.680 ; p<0.05\right)$. Helping Subordinates Grow \& Succeed performance in this study was measured by soliciting perceptions regarding the employees' 
performance. This finding therefore indicates that Servant leadership is predicted to significantly improve employees' performance.

\begin{tabular}{|l|l|l|l|l|l|l|}
\hline \multicolumn{2}{|c|}{ ANOVA ${ }^{\text {a }}$ Model } & $\begin{array}{l}\text { Sum of } \\
\text { Squares }\end{array}$ & df & $\begin{array}{l}\text { Mean } \\
\text { Square }\end{array}$ & F & Sig. \\
\hline \multirow{2}{*}{1} & Regression & 100.208 & 1 & 100.208 & 180.484 & $.000^{\text {b }}$ \\
\cline { 2 - 8 } & Residual & 38.865 & 70 & .555 & & \\
\cline { 2 - 8 } & Total & 139.073 & 71 & & & \\
\hline \\
a. Dependent Variable: Putting Subordinates First \\
\hline \\
b. Predictors: (Constant), Servant Leadership \\
\hline
\end{tabular}

\begin{tabular}{|c|c|c|c|c|c|c|}
\hline \multicolumn{7}{|c|}{ Coefficients $^{\mathrm{a}}$} \\
\hline \multicolumn{2}{|c|}{ Model } & \multicolumn{2}{|c|}{$\begin{array}{l}\text { Unstandardized } \\
\text { Coefficients }\end{array}$} & \multirow{2}{*}{$\begin{array}{l}\text { Standardized } \\
\text { Coefficients }\end{array}$} & \multirow[t]{2}{*}{$\mathrm{t}$} & \multirow[t]{2}{*}{ Sig. } \\
\hline & & B & Std. Error & & & \\
\hline \multirow[t]{2}{*}{1} & (Constant) & .101 & .298 & & $\begin{array}{l}.33 \\
9\end{array}$ & .736 \\
\hline & $\begin{array}{l}\text { Servant } \\
\text { Leadership }\end{array}$ & .813 & .061 & .849 & $\begin{array}{l}13 . \\
434\end{array}$ & .000 \\
\hline
\end{tabular}

\section{Table 8c}

Furthermore, from Table 8c Servant leadership explains a significant proportion of the variance in the dependent variable Putting Subordinates First performance $(F=180.484 ; p<0.05)$, and was found to have a significant and positive impact on Putting Subordinates First performance $\left(b^{*}=0.813 ; p<0.05\right)$. Putting Subordinates First performance in this study was measured by soliciting perceptions regarding the employees' performance. This finding therefore indicates that Servant leadership is predicted to significantly improve employees' performance.

\begin{tabular}{|c|c|c|c|c|c|c|}
\hline \multicolumn{7}{|c|}{ ANOVA $^{\mathrm{a}}$} \\
\hline & & Sum of Squares & $\mathrm{df}$ & Mean Square & $\mathrm{F}$ & Sig. \\
\hline 1 & $\begin{array}{l}\text { Regressi } \\
\text { on }\end{array}$ & 25.933 & 1 & 25.933 & 34.446 & $.000^{\mathrm{b}}$ \\
\hline
\end{tabular}


17 | International Journal of Scientific and Management Research 04 (04) 01-20

\begin{tabular}{|l|l|l|l|l|l|l|}
\hline & Residual & 52.700 & 70 & .753 & & \\
\cline { 2 - 4 } & Total & 78.633 & 71 & & & \\
\hline \\
a. Dependent Variable: Employee Retention \\
b. Predictors: (Constant), Servant Leadership
\end{tabular}

\begin{tabular}{|c|c|c|c|c|c|c|}
\hline \multicolumn{7}{|c|}{ Coefficients $^{\mathrm{a}}$} \\
\hline \multicolumn{2}{|c|}{ Model } & \multicolumn{2}{|c|}{$\begin{array}{l}\text { Unstandardized } \\
\text { Coefficients }\end{array}$} & \multirow{2}{*}{$\begin{array}{l}\text { Standardized } \\
\text { Coefficients } \\
\text { Beta }\end{array}$} & \multirow[t]{2}{*}{$\mathrm{t}$} & \multirow[t]{2}{*}{ Sig. } \\
\hline & & $\mathrm{B}$ & Std. Error & & & \\
\hline \multirow[t]{2}{*}{1} & (Constant) & 2.877 & .346 & & 8.304 & .000 \\
\hline & $\begin{array}{l}\text { Servant } \\
\text { Leadership }\end{array}$ & .414 & .071 & .574 & 5.869 & .000 \\
\hline
\end{tabular}

\section{Table 8d}

Furthermore, from Table 8d Servant leadership explains a significant proportion of the variance in the dependent variable Employee Retention performance $(F=34.446 ; p<0.05)$, and was found to have a significant and positive impact on Employee Retention performance $\left(b^{*}=0.414\right.$; $\mathrm{p}<0.05$ ). Employee Retention performance in this study was measured by soliciting perceptions regarding the employees' performance. This finding therefore indicates that Servant leadership is predicted to significantly improve employees' performance.

\begin{tabular}{|c|c|c|c|c|c|c|}
\hline \multicolumn{7}{|c|}{ ANOVA $^{a}$} \\
\hline \multicolumn{2}{|c|}{ Model } & Sum of & $\mathrm{df}$ & Mean & $\mathrm{F}$ & Sig. \\
\hline \multirow[t]{3}{*}{1} & $\begin{array}{l}\text { Regressi } \\
\text { on }\end{array}$ & 63.501 & 1 & 63.501 & 70.384 & $.000^{\mathrm{b}}$ \\
\hline & Residual & 63.154 & 70 & .902 & & \\
\hline & Total & 126.655 & 71 & & & \\
\hline
\end{tabular}




\begin{tabular}{|c|c|c|c|c|c|c|}
\hline \multicolumn{7}{|c|}{ Coefficients $^{\text {a }}$} \\
\hline \multirow{2}{*}{\multicolumn{2}{|c|}{ Model }} & \multicolumn{2}{|c|}{$\begin{array}{l}\text { Unstandardized } \\
\text { Coefficients }\end{array}$} & \multirow{2}{*}{$\begin{array}{l}\text { Standardized } \\
\text { Coefficients } \\
\text { Beta }\end{array}$} & \multirow[t]{2}{*}{$\mathrm{t}$} & \multirow[t]{2}{*}{ Sig. } \\
\hline & & B & Std. Error & & & \\
\hline \multirow[t]{2}{*}{1} & (Constant) & 2.168 & .379 & & 5.718 & .000 \\
\hline & $\begin{array}{l}\text { Servant } \\
\text { Leadership }\end{array}$ & .648 & .077 & .708 & 8.390 & .000 \\
\hline
\end{tabular}

\section{Table 8e}

Furthermore, from Table 8e Servant leadership explains a significant proportion of the variance in the dependent variable Employee Satisfaction performance $(F=70.384 ; p<0.05)$, and was found to have a significant and positive impact on Employee Satisfaction performance $\left(\mathrm{b}^{*}=\right.$ 0.648; $\mathrm{p}<0.05)$. Employee Satisfaction performance in this study was measured by soliciting perceptions regarding the employees' performance. This finding therefore indicates that Servant leadership is predicted to significantly improve employees' performance.

\subsection{CONCLUSION}

It was obvious from the findings of the study that employees favor the servant leadership personality in their organizations. Actually, such personality is necessary for the employee satisfaction and will have momentous impact on the workplace performance. Once the performance of employees is enhanced, productivity is boosted and a better corporate culture is established. At a later stage, the society would strive and follow less complicated approaches in seizing power distances that value the individual's input and output regardless of the economic or social status.

\section{REFERENCES}

Anderson, K. (2005). A Correlation Analysis of Servant Leadership and Job Satisfaction in a Religious Educational Organizational. Management. Arizona: University of Phoenix. Retrieved March 2019, from http://citeseerx.ist.psu.edu/viewdoc/download? Doi=10.1.1.454.9122\&rep=rep1\&type $=$ pdf

Barnabas, A., \& Clifford, P. (2012). Mahatma Gandhi - An Indian Model of Servant Leadership. Iternational Journal of Leadership Studies, 7(2), 132-150. Retrieved March 2019, from http://unpan1.un.org/intradoc/groups/public/documents/apcity/unpan050932.pdf

Cerit, Y. (2009). The Effects of Servant Leadership Behaviours of School Principals on Teachers' Job Satisfaction. Educational Management Administration \& Leadership, 37(5),600-623.RetrievedMarch2019, from http://citeseerx.ist.psu.edu/viewdoc/download? Doi=10.1.1.890.6473\&rep=rep1\&type $=$ pdf 
19 | International Journal of Scientific and Management Research 04 (04) 01-20

Denzin, N.K. \& Lincoln, Y. S. (2000). A handbook of qualitative research (2nd ed). Thousand Oaks, CA: Sage Publications, Inc.

Evaa, N., Robin, M., Sendjaya, S., Dierendonck, D. V., \& Lidene, R. (2019). Servant Leadership: A systematic review and call for future research. The Leadership Quarterly, 30(1), 111-132. Retrieved March 2019, from https://doi.org/10.1016/j.leaqua.2018.07.004

Fincham J. E. (2008). Response rates and responsiveness for surveys, standards, and the Journal. American journal of pharmaceutical education, 72(2), 43. Https://doi.org/10.5688/aj720243

Freeman, G. (2010). Spirituality and Servant Leadership: A Conceptual Model and Research Proposal. Emerging Leadership Journeys, 4(1), 120-140.

Hair, J.F., Black, W.C., Babin, B.J. \& Anderson, R.E. (2014). Multivariate Data Analysis. 7th ed. Upper Saddle River, NJ: Pearson.

Hulley, Stephen B.; Cummings, Steven R.; Browner, Warren S.; Grady, Deborah G.; Newman, Thomas B. (2007). Designing Clinical Research, 3rd Edition, Lippincott Williams \& Wilkins

Kaiser, H.F. (1991). Coefficient alpha for a principal component and the Kaiser-Guttman Rule. Psychological Reports, 68(3):855-858.

Marshall, C. \& Rossman, G. B. (1999). Designing qualitative research (3rd ed). Thousand Oaks, CA: Sage Publications, Inc.

Mayer, D., Bardes, M., \& Piccolo, R. (2008). Do servant-leaders help satisfy follower needs? An organizational justice perspective . European Journal of Work and Organizational Psychology, 17(2), 180-197. Retrieved March 2019, from http://dx.doi.org/10.1080/13594320701743558

Nardi, P.M. (2003). Doing Survey Research: A guide to Quantitative Methods. Boston: Pearson Education, Inc.

Nunnally, J.C. \& Bernstein, I.H. (1994). The assessment of Reliability.

Patterson, K., Russell, R., \& Stone, G. (2003). Transformational Versus Servant Leadership: A Difference in Leader Focus. The Leadership \& Organization Development Journal, 25(4), 349-361. Doi:10.1108/01437730410538671

Polit, D. And Hungler, B. (1999), Nursing Research: Principle and Method, 6th ed.; Philadelphia: Lippincott Company, P.P. 416-417

Savage-Austin, A., \& Honeycutt, A. (2011, January). Servant Leadership: A Phenomenological Study Of Practices, Experiences, Organizational Effectiveness, And Barriers. Journal of Business and Economics Research, 9(1), 49-54. Retrieved March 2019, from http://clutejournals.com/index.php/JBER/article/download/939/923

Sendjaya, S., \& Sarros, J. (2002). Servant leadership: Its Origin, Development, and Application in Organizations. Journal of Leadership and Organization Study, 9(2), 57-64. Retrieved 
20 | International Journal of Scientific and Management Research 04 (04) 01-20

2019, fromhttp://www.lead.fju.edu.tw/teacher/Lucia/course/Servant\%20Leadership/200209Servant\%20leadership\%20\%20It's\%20origin,\%20development,\%20and\%20applicatio n\%20in\%20organizations.pdf

Spears, L. (2010). Character and Servant Leadership: Ten Characteristics of Effective, Caring Leaders. The Journal of Virtues \& Leadership, 1(1), 25-30. Retrieved February 2019, fromhttp://www.vizenllc.com/wpcontent/uploads/2015/07/characherandservantleadership .pdf

Usman, A., \& Danish, R. (2010, April). Spiritual Consciousness in Banking Managers and its Impact on Job Satisfaction. International Business Research, 3(2), 65-72. Retrieved March 2019, from https://www.researchgate.net/publication/42385943 Work

Yahchouchi, G. (2009). Employees' Perceptions of Lebanese Managers' Leadership Styles and Organizational Commitment. International Journal of Leadership Studies, 4(2), 127-140. Retrieved March 2019, https://www.regent.edu/acad/global/publications/ijls/new/vol4iss2/IJLS_V4Is2_Yahchou chi.pdf

Zikmund, W.G., Babin, B.J., Carr, J.C. \& Griffin, M. (2009). Business Research Methods. 8th ed. Mason, $\mathrm{OH}$ : Cengage Learning. 